\title{
Queer Bolero: Bolero Music as an Emotional and Psychological Space for Gay Men in Cuba
}

\author{
Moshe Morad \\ Ono Academic College \& Tel Aviv University, Tel Aviv, Israel
}

\begin{abstract}
While researching musical genres and events as a space for identity among gay men in Cuba during the period of austerity known as the Special Period, I came across the role of sentimental and nostalgic Bolero music as an emotional and psychological space. This essay describes and analyses the characteristics of bolero music and poetry, such as its hybrid nature, the "self victimization" themes of its lyrics and their gender ambiguity, and its heroes/divas' life stories, and shows how they resonate with the life and psychology of older generation gay men in Cuba. It also describes and analyses the unique "private" ways of consumption of bolero, once a glamorous night-club genre, by gay Cubans during the Special Period, and how it became a strong vehicle for emotional therapy and an object for identification.
\end{abstract}

Keywords: Gay, homosexuality, queer, Cuba, bolero, music, emotional space

\section{Introduction}

Old-style, sentimental and dark bolero, which had its heyday in the 1930s and 1940s, re-emerged as an important emotional musical space among gay men in Cuba, during the "Special Period", a period of austerity and social instability due to the financial crisis that followed the fall of the Soviet Union and subsequent withdrawal of support to Cuba.

During my fieldwork in Havana, researching music and identity in the so-called gay ambiente (ambience, environment - the local expression equivalent to a "gay scene"), I discovered how an "emotional space" was created by listening to, miming and identifying with bolero.

In this essay, I demonstrate and deconstruct behavioral patterns and bolero poetry, and bring out the psychological and emotional elements that gays identify with, some going so far as to declare openly : "I am bolero, my life is bolero", a confession I heard several times in the course of my research. It is important to note that my discipline is ethnomusicology, not psychology, and therefore this essay is not a psychological essay per se and therefore does not engage in scientific psychological analysis. It describes how emotional and psychological "themes" are reflected in the genre and the way it is consumed in Special Period Cuba, creating a much needed emotional space.

Bolero is the first style of Cuban vocal music to gain international recognition, and furthermore the first globally known genre which fuses African and Hispanic elements (Orovio, 2004, p. 30). Originally a Cuban lyrical form created in the late nineteenth century, bolero since the 1920s has been evolved by pianists and

\footnotetext{
* This essay is based a chapter from my book: Fiesta de diez pesos: Music And gay Identity in Special Period Cuba (Ashgate, 2014). Moshe Morad, Ph.D., Ono Academic College \& Tel Aviv University.
} 
composers into a romantic/dramatic genre. The centre of bolero activity and creativity has migrated from Cuba to other Latin American countries such as Mexico and Puerto Rico since the 1930s, but maintained a strong Cuban identity. Cuban musicologist Orovio claims that the various influences it acquired along the way, such as the addition of percussive instruments from the son tradition, only "confirm that the development of this style of bolero is purely Cuban and not affected by other countries, as some suggest" (Orovio, 2004). Bolero oscillates between local/Cuban and international/global identities. Its "Cubanness" is an important factor of the appropriation of bolero by those trying to maintain or recreate a nostalgic pre-revolutionary identity, one of the main pillars in gay identity formations in Cuba, as will de discussed in this essay.

The 1885 composition "Tristezas" ("Sadnesses”), by Cuban trova composer José Pepe Sánchez is one of the first bolero songs, and its title encapsulates the emotional context of the genre, sadness being its main theme and raison d'être. Cuban bolero arrived from the provinces to Havana in the 1920s where it was developed further by skilled composers and pianists, and soon migrated to Mexico and Puerto Rico. By adding a twist of dramatization, romanticism, and what some call "kitsch" (Acosta, 1996), influenced by the local tradition of mariachi serenading, Mexicans "brought a different sensibility to the bolero" (Sublette, 2004, p. 484). The genre was yet to acquire another layer of non-Caribbean melancholy and romance before it would reach international fame as the ultimate, tear-jerking genre of all times.

The existing literature on bolero and its queer appeal concentrates on Latino and Latina gays in general, mostly in the United States (Zavala, 1990; Aparicio, 1998; Quiroga, 2000; Knights, 2001). I, however, focus on the unique circumstances in its birth place, Cuba, and show how it made a come-back and provided an important and unique emotional space for Cuba's gays during the Special Period, a "space" different from this offered and occupied by bolero in gay communities outside Cuba. One major difference is the geographical aspect and the a non-availability of live bolero concerts - whereas the focal point and main location of bolero activity as discussed by the above - mentioned authors is the night-club performance, my focus is on the unique situation in Cuba in which bolero is experienced by local gay men mostly as recorded and mimed in privacy at home, or in improvised, clandestine soirées (bolero fiestas) and drag shows as will be described hereunder .

Bolero is essentially tragic and extreme, “... if any love song taps the vein of sentimentality, bolero cuts that vein with a razor blade", writes Quiroga (2000, p. 154). It can be "too much" to Eurocentric ears educated to restraint extreme emotions. One frequent observation made about bolero in many of my conversations, especially with North American and European gays, was that it is "Camp". ${ }^{1}$ What makes Bolero Camp is its melodramatic music, the over-emotional lyrics, and not least its theatrical, "over the top" performance, such as the tears and quivering lips of Olga Guillot and the wild groans of La Lupe. ${ }^{2}$ Unlike drag artistes most bolero writers and composers, as well as most performers, do not intend to be Camp. They mean to be expressive, and dramatic, but not Camp. They become Camp from the point of view of the audience's "gay sensibility". As Susan Sontag puts it, "( $\mathrm{t}$ )he pure examples of Camp are unintentional; they are dead serious... Camp which knows itself to be Camp ('Camping') is usually less satisfying” (1964).

\section{Mapping Bolero Consumption Among Cuban Gays: Demography, Geography, Psychology}

Profiling the "bolero target group" within the gay ambiente can be tricky. Most common factors seem to

\footnotetext{
${ }^{1}$ Camp is an aesthetic "gay" sensibility which values things or attitutudes because of their ridiculousness and exaggeration, as described in Susan Sontag's 1964 essay "Notes on 'Camp".

${ }^{2}$ Both singers will be featured later in the chapter.
} 
be psychological and identity-driven, rather than social. From over 200 Cuban gays in Havana with whom I have had different levels of conversations, I compiled the following average profile of the bolero gay sub-group: those who consume bolero, enjoy it, and identify with it. They are over forty years old, come from different backgrounds (original habaneros or "migrants" from the provinces), are of mixed racial combinations (white, mulato, black). In this group, there is a high percentage of effeminate homosexuals, those admitting to be "passive" in their sexual tendency, a high number of locas ("raving queens"); a high degree of transvestites, transsexuals, and those who perform or enjoy drag shows.

A gay Mexican bolero expert and collector frequently visiting Cuba, told me that in Mexico and Puerto Rico "bolero fans today are more educated, 'middle class', and white". My experience in Cuba was different and perhaps more "egalitarian". I attended bolero fiestas and met aficionados in black poor neighborhoods, as well as among a university-educated, sophisticated crowd.

In spite of the European image of the genre, bolero lovers come equally from all sections of Cuban society. ${ }^{3}$ From within the sub-group of gay bolero aficionados identified among my network of informants, I chose two as my main bolero informants, both for being "typical", addicted bolero lovers, "well connected" and known in the gay ambiente, and ready to meet repeatedly and talk or, as they have put it "open their hearts", Angelito and Aurelio.

The geographical place of the bolero experience in the gay ambiente, is mainly a private space, usually individual rather than social. The economic situation prevents Cubans from entering the expensive clubs featuring live bolero music, and furthermore many of these clubs deny admission to males unaccompanied by females, supposedly as an attempt to reduce sex work and solicitation inside the club. I have experienced myself three unsuccessful attempts to enter bolero clubs such as Pico Blanco and El Gato Tuerto in Havana with a group of male friends only. The reason that was given in all three occasions was the policy of not admitting men or women alone, only mixed couples. The physical space which once bolero offered to Havana's gays (nightclubs and cabarets), has changed - from the public to the semi-private and completely private, turning bolero into a non-physical, albeit very substantial, emotional space.

With the unavailability of bolero nightclubs for local gays, private bolero soirees and drag shows using recorded bolero music mimed by amateur performers, are perhaps the main social outlet and space dedicated to bolero. However, most of the action takes place in a very private domain - at home, listening to bolero cassettes or CDs alone or with friends, feeling empowered and transformed by the music, and creating via the music, a much needed emotional space.

My first experience in this private kind of bolero event was in 1997. Angelito was a forty-five-year-old loca, as he calls himself, who swings erratically from loud laughter to tears, from joy to sudden melancholy. He lives in a central Havana flat with his elderly mother and some young "friends" who sometimes stay overnight. $\mathrm{He}$ rents rooms to gay tourists. He transforms from behaving macho in front of policemen and officials frequently visiting and inspecting the notorious flat, to becoming a flagrant loca when entertaining his guests.

\footnotetext{
${ }^{3}$ In Cuba, education is free for all, and Cuban society is supposed to be egalitarian. In the course of my fieldwork, there was a gradual move towards a more obvious social polarization between educated (university, well-read) and non-educated (basic education, mostly from rural/provincial background, or from poor, mostly black, Havana neighborhoods); and between some kind of a "middle class" mostly white (those with access to CUC, working in the tourist industry or trading with foreign companies, or with supporting families abroad, communist party officials, close to the regime and its various institutions, and, controversially, jineteras/os, sex workers and hustlers with tourist supporters), and a "lower class" (black, living in poor neighborhoods, mostly black, "not connected" or with no relatives abroad). These social distinctions exist also within the gay community in Havana.
} 
But when he puts on his favorite bolero cassettes while doing the dishes, he turns into his real self (so he claims), expressing his true feelings and persona. His favorites are La Lupe, Olga Guillot, and Elena Burke. As soon as he turns on the cassette-player and the music starts, he enters into "bolero mode"-his movements and body language change, entranced with blurred eyes, distant and transfixed upon a blank point in the wall. He sings the lyrics loudly and expressively and wipes off a tear with his sleeve. Here with his bolero, in the midst of the chaos of a busy central Havana flat packed with friends, family, clients, hustlers, and the occasional inspector coming in and out, Angelito finally enters his own private space, an inner, emotional space conjured up by the melancholic sounds of bolero. He calls it "kitchen bolero", and sees it as his personal brand of therapy. I have adopted the term "kitchen bolero" to describe this particular musical space- the bolero listened to, mimed, and sung by individuals in the privacy of their homes, transferring them to a world of deep emotion and fantasy.

Indeed, the performance of bolero in the context of this investigation is mostly experienced on cassettes or $\mathrm{CDs}$, or a miming performance to a recorded soundtrack. A recorded piece has its own performative and semantic power and meaning. "At once futurist and nostalgic, sound recording (shifts) the felt nature of memory, time, and place, disrupting the naturalized chronotope of live performance and producing an epistemological divide between face-to-face and mediated communication..." (Samules, Louise, Ana, \& Thomas, 2010, p. 332). Furthermore, even when listening to bolero in public, the experience is mostly psychological and internalized, even meditative, between the listener and himself, or between the listener and an imagined sphere. I was told by informants that "bolero can be felt", "can be heard inside", a mood rather than a musical genre.

When asking gay bolero-lovers to describe bolero and list different ideas, conditions and characteristics they associate within bolero, nearly everyone mentioned the word "desire". Some mentioned the "power" of bolero: "it is powerful" (poderoso), "it gives me power". Leppert sees "desire" and "power" as the main discursive particularities in any "sonoric soundscape": "The category "desire' provides me with an entry into the embodied relations between the private and public" (1998, pp. 294-295). In bolero, desire is essential, both semantically (lyrics) and emotionally. Bolero is indeed a space which embodies relations between the private and the public, as I will show in this chapter.

Other themes/characteristic of bolero that repeatedly emerged in my conversations with gay bolero fans were sexual ambiguity, Camp, melancholia, nostalgia, hysteria, deception, betrayal, and living "in between" or "on the border". Not surprisingly, these same traits were also mentioned when the conversation switched from bolero to their own life experiences, hence the strong identification with bolero.

The Nostalgic urge is also expressed in the choice of repertoire. Many of the songs I heard in my first bolero fiesta in 1995 were also the ones I heard throughout twelve years of repeated visits in bolero fiestas and at the homes of my informants who labeled them as their favorites and the ones they most identify with. Unlike dance music genres in the ambiente, in the case of bolero the "musical taste" remained stable and enduring without any change. Taking that nostalgia is one of the themes embedded in both bolero and gay discourses, this adoration and preservation of the "oldies" is not at all surprising.

\section{"Bolero Mode": Description of a Bolero Fiesta}

I was invited to a bolero fiesta at the home of Raúl (47) and Alejo (35), a gay couple I had met on one of my strolls down the streets of old Havana. They lived in a rundown but rather large apartment on the fifth floor of a decaying colonial building. I was taken to a large, dark room which was lit by candles as there was a power 
cut in the neighborhood (a very common occurrence in Havana during those years). Twenty men, some in their twenties and some over fifty perhaps, were drinking beer and cheap rum, smoking, and talking.

About forty minutes later, the lights came on, an old portable cassette-player was quickly plugged in, and the event began with some boleros by singer Olga Guillot. The loud chatting stopped instantly and everyone switched into a "bolero mode" with facial expressions changing, looking emotionally tense and in some cases even distraught. People began miming and singing, each staring up at an imaginary point (heads uplifted at $120^{\circ}$ angle), making gestures with their hands and faces, dramatically expressing pain, anger, or passion, and sometimes all three simultaneously.

The impression was one of a temple during a ritual, and some of the audience looked as if they were in a state of trance. Soon three guys in drag (dresses, high-heel shoes, make-up, and wigs) joined the gathering, emerging from the bedroom, where they had been getting ready, each one miming to a song in turn. Only some of those present remained merely watching, while the majority joined in the singing and miming together with the drag artistes.

This ritual of changing cassettes, singing, miming, mimicking "diva" gestures, and staring skywards continued for a couple of hours. However, unlike people in a state of trance who are completely absorbed in their activity, the party-goers here serenely switched in and out of the "bolero mode". When they were not joining in with the performers, they simply sat at a corner, drinking and chatting together, occasionally laughing at the performers' antics or clapping wildly at a particularly impressive rendition. Couples could be seen kissing and cuddling freely, evidently emboldened by the romantic music and the intoxicating atmosphere.

Although many of the songs were clearly sung in the second person, to a lover, man, woman, some object of passion or betrayal, or the like, the performers rarely aimed their song at anyone in particular in the gathering, but rather at that same blank point above their heads towards the ceiling, as if at some invisible entity, a pose that made the entire event look even more surreal, at times even ritual and religious. "Boleros are sung to no one in particular", observes Quiroga (2000, p. 155), "or to someone always outside: they are voiced to a subject beyond the public, so that he or she can take stock of the afflictions of the present and offer redemption". This kind of performance style is modeled on the performance of singer/diva Olga Guillot, one of the favorite performers of gay Bolero fans in Cuba and one of the most impersonated figures by Cuban drag queens. The repertoire played that evening consisted of classic Cuban and Mexican boleros, by such boleristas as Benny Moré, Elena Burke, Orlando Vallejo, Ñico Membiela, Orlando Contreras, Roberto Faz, René Cabel, Fernando Albuerne, Olga Guillot, Chavela Vargas, Omara Portuondo, Daniel Santos, Blanca Rosa Gil and La Lupe. Later in the evening the hosts played some rare old recordings of bolero pioneers, such as Roberto Sánchez, Lino Borges, and Fernando Alvárez. The richness, drama, and "glamour" of the music, usually associated with plush 1950s nightclubs, stood in defiant contradiction to the sparseness of the apartment, with its bare walls and broken furniture. The party at Raúl and Alejo's was not a one-time event. I have since attended many such "gay bolero fiestas" in Havana.

\section{An Imagined Audience}

In spite of its internal emotional character, bolero has an audience, even when experienced in private - an imagined audience. In both bolero experience forms described here-bolero fiestas as a social event with a physical audience, and "kitchen bolero", when bolero "performance" is experienced solitarily in one's kitchen or bedroom, it is still an act of performance and performativity, and the audience is of the same kind - an 
imaginary, or rather imagined, audience. The audience in the bolero fiesta described above was "trapped" in that blank point above the singer/mimer's head his eyes were fixed upon, or in fact in his own head, and not the group of people present in the room, sitting or standing, and watching him. The same "imagined audience" is there in Angelito's kitchen where he mimes to his favorite boleros and points its gestures to an invisible entity, and not to me, the only physical "audience" in the room.

Therefore, I argue that the space which bolero provides is still based on the triangular relationship between performance, performativity, and audience. Still, it is an "emotional space", and as such the performance, the performativity and the audience, although having some physical expressions (mimicking, gesturing, staring at a blank point), just like the space itself, are emotional/internal rather than geographical/physical. The performance is imaginary, the gender performativity is imaginary, and so is the audience, whether the "performer" aims its performance at a large imagined audience (imagining he is a diva on a stage) or at an imagined individual (completely imagined, or a real person he craved for or had a painful affair with in the past, now enlivened by his imagination).

\section{Gender Ambiguity in Bolero Lyrics}

An important characteristic of bolero lyrics, is their discursive gender/sexual ambiguity (Zavala, 1990; Quiroga, 2000; Knights, 2001, 2006; Aparicio \& Candida, 2003). Bolero lyrics allow-and even celebrate - sexual and gender ambiguity. Most boleros are sung in second person and not addressed to a specific named person (Knights, 2006, p. 86). In Spanish (as in English), a conjunct verb is genderless and so is the second person "you" (tú, usted) which can refer to either male or female, so a sentence like "I love you" or "I miss you", can be addressed by both genders and to both genders (and also from/to transgenders). For example, one of the most famous boleros, and a favorite of Cuban gay bolero aficionados is "Tú me acostumbraste" ("You got me accustomed to"), written by Frank Domínguez. The song was rumored to have been written to another man (Aulicino, 2007). It was recorded by both male bolero stars such as Luis Miguel and Luis Hector, and by female singers including Cuban bolero divas Olga Guillot and Elena Burke, and Mexican openly-Lesbian singer Chavela Vargas. The lyrics are not only "gender ambiguous", but are also open to various queer interpretations.

The song is sung (in second person, as usual) to an ambiguous tú (you) and, as in many bolero songs, the performer is the "weak" one in the relationship (the betrayed, the heartbroken).

It starts with the line "You got me accustomed to all these things, and you taught me how wonderful they are" ${ }^{, 4}$ which can be interpreted as a coded reference, as in "these things that we don't talk about". It goes on to "You subtly came into my life", which can be interpreted as in a secret relationship. The line "I did not understand how to love in your "rare' world, and I learned thanks to you" can easily fit into a homoerotic narrative. That is, "I was inexperienced and you taught me the secret of homosexual love". The expression raro was used in old-fashioned gay discourse to indicate "gay" in code. This queer interpretation of the famous song was affirmed and reaffirmed by many gay bolero fans informants, and I have seen many drag queens expressing these "special codes" by exaggerating facial and manual expressions when miming or singing them. For example, Amanda in a private drag fiesta extended her lips expression (as if whispering) and then put her finger on her mouth indicating a secret when miming "these things that we don't talk about"), and when

\footnotetext{
${ }^{4}$ From: "Tú me acostumbarste" Lyrics: Frank Domínguez. My translation.
} 
miming "in your 'rare' world" pointed at her backside referring to homosexuality signified by anal intercourse (drag show in old Havana, 1999). Aparicio described this phenomenon as the "meanings (that) are produced among lesbian and gay interpretive communities that continue to consume boleros as texts that articulate desire between homoerotic lovers" (1998, pp. 138-139), facilitated by the fact that gender is "already destabilized in this particular musical sensibility given the open-gendered nature of the yo (I) and the tú (you)" (Aparicio, 1998).

The fact that the genre is characterized by a separation between writers/composers and performers adds another layer to bolero's gender ambiguity and flexibility. Bolero is a genre characterized by famous composers on one side (both female and male), and famous performers on the other. Unlike other Cuban genres such as son, nueva trova or timba, it is not a singer-songwriter genre, yet it is still "very personal" in its lyrics and performance style; the performer needs to strongly identify with the lyrics in order to sound "credible". It was written by either male or female writers/composers and performed by either male of female performers, and relays a strong message of erotic desire, and thus needs to be gender-ambiguous in order to allow both males and females to perform it credibly. The next step based on this paradigm, is the "queerification" of bolero, as whatever can be easily "switched" from male to female or from female to male, can also be "naturally" interpreted from male to male, or from female to female, in most cases without altering the lyrics.

The discursive gender ambiguity of bolero does not mean there is no reference to "woman" or "man" as an object, or femininity and masculinity as a concept. In fact, "woman" and "femininity" are strongly represented in bolero, but in a very special, and sometimes unconventional and controversial way, challenging society's gender conventions. Aparicio (1998, p. 184) notes that bolero lyrics are "a musical space in which woman (or the feminine) is constructed mostly as absence — an absence that stimulates the expression and articulation of male desire through the text/song and through the act of singing". But is it a male desire for "woman" or for the "feminine"? Knights claims that "(t)he conventions of the bolero provide a sanctioned musical space within which men can cathartically express their emotions and sensitivity, traditionally feminine attributes without compromising their masculinity (2001, p. 2), or as Aurelio states, “(i)t's the only Cuban genre where it's OK for men to be drama queens" (personal communication).

At the same time, bolero offers "a sanctioned outlet for women to express sexual desire, passion and anger, traditionally masculine qualities" (Knights, 2001, p. 2), "subverting the gendered binary division of masculine activity and feminine passivity" (Knights, 2006, p. 85, based on Aparicio, 1998, pp. 130-132). This "free, active woman" concept is expressed in many bolero lyrics who feature a decadent femme-fatale, or even a woman as a whore, a concept which is celebrated rather than denigrated (Knights, 2001), especially in the gay world which admires strong, diva-esque women (who also are perfect subjects to impersonation by drag queens). The acceptance, and even glorification, of the feminine-sensitive man on one hand, and the masculine super-woman (the "diva") on the other, belongs to the conceptual universe of bolero and to gay men.

Furthermore, in the cases that words are gendered (such as adjectives or nouns), conjugation is applied to alter the subject from feminine to masculine according to the gender of the singer, which also allows interpretation of male-written boleros by female singer, as well as, in our case, a homoerotic interpretation. Aparicio gives the example of Augustín Lara's "Perdidas" (lost women), who become "Perdidos" (lost men) when performed by female singer Toña La Negra (1998, p. 138). I encountered a similar "sex-change" with the same verb, when in 2003, in a bolero fiesta, I saw a drag queen performing Chucho Navarro's famous bolero "Perdida" while aiming it at a young gay man in the audience who had just ended a long relationship, singing at 
him: "Perdido (originally: Perdida)... people call you 'lost', without knowing that you suffer from despair". The "lost" boy strongly identified with the song and was in tears. Zavala describes this grammatical-sexual orientation phenomenon in these words: "the communicative triangle emisor/mensaje/receptor (speaker/message/receptor) is continuously destabilized as to gender infections" (Zavala, 1990; Aparicio, 1998, p. 138).

The phenomenon of "queerification" of lyrics and destabilized gender performance can be found in other "emotional song" cultures. In an essay about representation of homosexuality in recordings of German pre-war cabaret songs known as schalgers, Anno Mungen (2006, p. 68), talks about the process of "queering the song":

Although the songs in many cases revealed erotic contexts, gay performers — as the recordings show — usually did not come up with their own lyrics or music but mostly performed "straight" songs in their own manner, re-creating the existing music and situating it in a new performative context. The recordings of these songs reflect the model of the straight world creating gay identities through artistic expression. (Mungen, 2006, p. 69)

Another way of queer appropriation is via performance and body language - dance, gestures, drag (Mungen, 2006, p. 77). Mungen talks about two levels of appropriated schlager performance (also the case in bolero): mediatized (the recording or the stage performance by the singer) and live representation by dancers-listeners (secondary re-creation of the performance, by way of dance, drag shows, and "kitchen bolero"). Both schalger and bolero genres are extensively used in drag shows in Germany and Cuba respectively. ${ }^{5}$

\section{Psychological Themes in Bolero Lyrics: "Like a Knife Stuck in Your Heart"}

I can identify with the lyrics of so many (bolero) songs. I hear a song and I say "this is the story of my life". The words are painful, as they bring back memories of things that happened to me, but I love hearing them. Hearing and crying. I guess I am a masochist. Some of the lyrics are like a knife stuck in your heart (Aurelio, 44, personal communication).

The main aspect of bolero which evokes identification by its gay fans is its lyrics. Nearly all informants, above 40, whom I asked to quote bolero lyrics, knew quite a vast repertoire of songs. Bolero poetry is known for its "unrestrained romanticism or sentimentality" (Campos, 1991, p. 637). The words written by researchers about the lyrics of Bolero are just as dramatic as the lyrics themselves: "Bolero lyrics are defined by the bitter aftertaste of pain that accompanies passion" writes Domínguez (1993, p. 80, as cited in Knights, 2001, p. 1). According to Zavala, "it speaks the language of desire, of its absence and presence, of illusion and disillusionment (1990, as cited in Knights, 2001, p. 1). It expresses the desire for "the unattainable other" (Knights, 2001, p. 2), and glorifies it. One might well say that all these themes, especially that of the kind of desire that by definition is impossible to realize, have been plucked straight out of the emotional and social world of older-generation Cuban homosexuals, many of them bolero aficionados.

Despite their being so overtly romantic, in many cases bolero lyrics also express resistance to love and excessive romanticism. As Knights puts it: "The bolero is a complex and contradictory form, a potentially conservative discourse which simultaneously provides the opportunities for resistance to structures of domination" (2001, p. 11).

Common themes in bolero poetry which are particularly resonant with gays in Cuba include living in danger, suffering from chronic heartbreak, being betrayed and being lied to, living in disguise, and being

\footnotetext{
${ }^{5}$ See Chapter 9 about performance/performativity in drag shows.
} 
"prohibited". Here are some short extracts from songs I have frequently seen "performed"6 in a "bolero mode" in gay bolero fiestas or privately, at home, in "kitchen bolero", demonstrating these themes.

\section{Danger}

The famous bolero "Amor robado" was performed in the bolero fiesta I described in the introduction. The "performer' sang the lyrics: "I know that this poison is deadly, the one you offer with your beautiful lips. Gambling on my life with a kiss. Mischievous, alien and dangerous love..."7.

While emphasizing the words mortal (deadly) and peligroso (dangerous) by twisting his face with a painful/fatal expression, rolling the "R"s exaggeratedly, shaking his head from side to side rapidly, making a fist with the left hand and holding it close to his chest/heart. At this particular performance the "performer" did not direct his stare to an individual but at a blank point in space, in a typical "bolero mode". However, at another bolero fiesta as well as at drag shows, I saw the "performer" directing the quoted lyrics at a handsome, young, macho-looking man in the audience, expressing the theme of "danger" gays face when falling in love with young heterosexual men, a "mischievous, alien and dangerous love".

As Aurelio told me: "we are used to living in danger. It is dangerous to fall in love with a macho buggarón. You know you are going to suffer at the end. He will either rob you or beat you up, or break your heart" (personal communication, 2000).

\section{Suffering}

Two bolero classics I frequently heard in gay bolero fiestas and drag shows were "No puedo ser feliz" (I cannot be happy), and "Delirio" (delirium).

"No puedo ser feliz" is one of homosexual musician Bola de Nieve's most famous boleros, and a "classic" in the cassette/collection of all gay bolero fans I met in Havana. A whole section will be dedicated later in this chapter to Bola de Nieve, the first and only "openly homosexual" in the hall of fame of Cuban music. When he sings "I cannot be happy, I cannot forget you, I feel that I lost you...", 8 many old-time gays in Cuba identify with the melodramatic lyrics and feel of the song.

"Delirio" has an even clearer message of "love equals suffering" with lines such as: "This delirious love which burns my soul. This passion which torments my heart..."9

Arsenio Rodríguez's "La vida es un sueño" (Life is a dream) is another "identification" anthem among gay bolero aficionados. "Living in a dream, in a constant illusion, is something we all do", tells me Angelito, who has the lyrics written in his personal diary to which he always refers. "It is the only way to survive here (in Special Period Cuba), especially for us gays. We live in a dream as protective means, because the real life is all about suffering". He particularly likes quoting from the song "You have to take into consideration that everything is a lie, that nothing is true. You have to live the happy moment, enjoy what you can. Because when you add it all up, life is a dream and nothing lasts forever.... Everything is but an eternal suffering. The world is made of unhappiness." 10

\footnotetext{
${ }^{6}$ I put the word "performed" in quotation marks as the performance I describe is actually a "performance of a performance", when the "performer" mimes the recorded song played from a sound system and with his/her own gestures and mimics gives the song its meaning. The same applies of course to drag shows (Chapter 9) where most songs are mimed and "recycled".

7 From "Amor robado" (Robbed love), by Esteban Taronji (My translation).

8 From "No puedo ser feliz" (I cannot be happy), by Adolfo Guzmán (My translation).

9 From "Delirio" (Delirium), by César Portillo de la Luz (My translation).

10 From "La vida es un sueño" (Life is a dream), by Arsenio Rodriguez (My translation).
} 


\section{Betrayal and Lying}

One of the most known bolero standards all over the world is "La última noche" (The last night). Again I have seen many tears shed in bolero gay fiestas when the "performer" sang or mimed: "Why did you leave that night and did not come back? You left me that night that cruel memory of your betrayal"11. My "gay bolero interpreter", Auerlio explains: "This song is typical to our world. These guys come at night, full of love, affection and promises. They are going to leave their wife and live with you forever.... You never see them again... when you are young and innocent you ask 'why'-like in the song. After that, you stop asking. You become used to be betrayed and lied to. You just cry inside..." (personal communication).

Betrayal is a theme that appeared regularly in the life stories of many of the older (over 40 years old) gays I met in Havana. In some conversations, this feeling of chronically being betrayed has expanded above the personal level. Being betrayed by society and by the authorities emerge from stories of neighbors reporting gays to the CDR and police, co-workers reporting them to the "bosses", teachers whose personal lives were reported to the university authorities by co-teachers and were fired just because of their homosexuality.

Lying is another reoccurring theme in many boleros I heard throughout my fieldwork. Some other examples with "lie" being the main theme and even part of the title: "Mentiras tuyas" ("Your lies") by Elena Burke; "Eso es mentira" ("This is a lie") and "Mientes" ("You lie") by Blanca Rosa Gil; "Miénteme" ("Lie to me"), "La mentira" ("The lie") and "La mentira se te olvida" ("The lie is being forgotten") by Olga Guillot.

Interestingly, when it comes to lying, many gays admit not only to being lied to and being victims of lies, a feeling expressed in the lyrics of " CCuidado!" quoted above, but also to having to lie themselves, and having to "live in a lie", "to put a mask on" (a concept which is discussed in the upcoming section about Bola de Nieve).

“iCuidado!” (Beware), by Chico Navarro, was a song I frequently heard in gay bolero soirées, with an emphasis of the performer on the line "Beware with your lies, which I can clearly detect when you look at me..."12. "This is the story of my life" whispered to my ear Aurelio in one of these evenings, when this line came up.

Deceit is indeed a popular theme in bolero poetics. In fact, Quiroga claims that "Bolero is all about deceit" (2000, p. 156). It expresses an "erasure" of all that exists, and a desire that is not real, but "a mental construction imposed on the real" (Quiroga, 2000, p. 152). I heard the same claim from Aurelio: "For us old-generation homosexuals, bolero is about deception, we are deceiving ourselves, closing our eyes and thinking we are on a stage, and dreaming about the perfect man who will love and possess us (personal communication)". Angelito, however, interestingly reversed the concept of bolero-as-deception: "I always have to act, to be someone else. This is the only way you can survive here. Sometimes I act so much I forget who I really am. Only when I listen to my (bolero) music I tune into my real self, my inside. I stop pretending to be strong or crazy" (personal communication).

One of the most popular boleros among Cuban gays is La Lupe's "Puro teatro" ("Pure theater"), which is all about being deceived, telling (in second person) to the deceiver, who is asking for forgiveness that his words are just "pure theater, well-rehearsed falsehood, well -studied simulation". When the deceiver/betrayer is asking

\footnotetext{
${ }^{11}$ From "La última noche" (The last night), by Bobby Collazo (My translation).

12 From “¡Cuidado!” (Beware), by Chico Navarro (My translation).
} 
for forgiveness, the deceived performer answers: "I don't believe you, I think that it is all theater", and dramatically declares: "this was your best show-destroying my heart". ${ }^{13}$

\section{Being Prohibited}

Being a prohibited sexual object for heterosexual men, is something many old generation Cuban gays learnt to live with, living in the fantasy of loving real men and living with them, but having to put up with being used and abused only for sex or money by buggarones and by married men, "prohibited" for real love. A song that many of such old generation Cuban gays identify with "' as expressing this "norm" of pre-gay homosexuality in Cuba is "Lo prohibido" ("The Prohibited"). Aurelio mimes the song dramatically in his kitchen, with a tragic expression on his face:

"I am that kiss that is given without being able to tell anyone, I am this name that you will never pronounce outside, out of here. I am this love which you will always deny to save your dignity. I am the prohibited". ${ }^{14}$

When the song ends he pauses with tears in his eyes, and tells me:

This song is about me. Yooo soy el prohibido (I am the prohibited)! D-The bastard, for years whenever he wants to fuck a man or to get a blow job knows where to find me, but even when we were closer and meeting nearly every day, he never dared walking near me in the street and would ignore me whenever he saw me on the street by chance. I asked him once when we were "in love" and he even told me how much he loves me. "Can we ever become a couple like C-and R-(a gay couple living together, neighbors of Aurelio)?" And he said "No way. Never. I will only marry a real woman". And (he) was angry at me for thinking about it. He is now married to this mulata, but once in a while he comes here for sex. "I am still in love with him, and every time he goes back home I cry" (personal communication).

\section{“Bolero State-of-Mind": Bolero Psychology}

"When I hear it (bolero) all my senses become alert, I get into a special mood, it's a bolero state of mind" (Juanito 55, personal communication).

This section looks into various psychological themes which kept recurring in the numerous conversations I held with informants about both bolero and "life" as gays in general. Gay bolero aficionados I spoke with mentioned the same themes in both contexts, bringing a psychological layer to the connection between bolero and gays, a connection manifested in the phenomenon of "bolero mode" kind of transformation that gay bolero fans go through, as described in the previous pages. The recurring common themes I refer to include: melancholia, nostalgia, hysteria, feeling rejected, being "on the border" or "not here and not there", and feeling "international". 15

\section{Melancholia}

The most common term my informants (gay and non-gay) used to describe bolero music was "melancholic". Bolero's melancholy is evoked both by the music (melody and rhythm) and by the lyrics. Musically, it is expressed by the slow-paced sadness of the melody, the minor scale of most bolero compositions, and a destabilization of rhythm caused by an alteration between syncopated and non-syncopated rhythmic units. ${ }^{16}$

\footnotetext{
13 From "Puro teatro" (Pure theatre), by Curet Alonso (My translation).

14 From "Lo Prohibido" (The prohibited), by Roberto Cantoral (My translation).

15 This is not psychological research, and therefore the terms and concepts are used in their colloquial meaning, and the few psychological literature references mentioned are brief and concise.

${ }_{16}$ This is based on a theory I developed regarding the connection between syncopation and melancholy.
} 
As for the lyrics, as demonstrated above, they compound the genre's intrinsic melancholia in a sense of tragedy and denial. Quiroga distinguishes between the melancholic sadness associated with samba and that of bolero: "Samba may invoke the sadness that accompanies the morning after a night of reckless abandon, but boleros insist on remaining in that night, in that space" (2000, p. 152). Bolero songs are strongly associated with disaster, but "( $\mathrm{t}$ )hey do not prepare you for the inevitable disaster: they want and beckon the constant reappearance of disaster. Boleros proclaim denial as a mode of affirmation" (Quiroga, 2000).

This "melancholy/gay connection" in the 1990s emerged to the surface, making bolero a signifier of a gay world, where bolero is voiced "via the melancholic homosexual as a polemical figure of mourning and celebration” (Quiroga, 2000, p. 149). Gay Spanish director Pedro Almodóvar's films are a good example of how bolero music is used in association with melancholic queer scenes and heroes; for example, Bola de Nieve's music in "Law of Desire", and La Lupe's music in "Women on the Verge of a Nervous Breakdown". Another example is "El último bolero" (The Last Bolero), a bittersweet Cuban theatre play by Cristina Rebull and Iliana Prieto (sister of Culture Minister Abel Prieto), which tells the story of reunion between a woman who left Cuba with her gay son and her daughter who stayed in Cuba. When asked about the title, the director says that the characters are "bolero": “...muy melodramático, pero con él te puedes reír, te puedes enamorar..." (...very melodramatic, but you can laugh with it, and you can fall in love with it...). ${ }^{17}$

Another connection to melancholia is related to the prohibition associated with homosexuality, one of the themes featured in the previous section: "(I)n the case of a prohibited homosexual union, it is clear that both the desire and the object require renunciation and so become subject to the internalizing strategies of melancholia", writes Butler (1999(1991), pp. 79-80). Gender-identity and the taboo on homosexual desire are other sources of melancholia: “. . . a kind of melancholia in which the sex of the prohibited object is internalized as a prohibition. This prohibition sanctions and regulates discrete gendered identity and the law of heterosexual desire ... the taboo against homosexuality" (Butler, 1999(1991), pp. 85-86).

Bolero lyrics often portray strong and even exaggerated self-victimization, self-blame, and self-criticism, feelings Freud associated with melancholia (Butler, 1999(1991), p. 83). This gender-identity complex, guilt-feelings, and the taboo of homosexual desire that underlie Freudian melancholia, are fundamental ingredients of queer bolero.

\section{(Invented) Nostalgia}

Nostalgia is one of the main feelings evoked by bolero. However, in most cases, this nostalgia is invented and represents longing for a glamorous period that had never really existed for most of the people who indulge in it. ${ }^{18}$ According to Mexican writer Carlos Monsiváis, bolero brings "the passion for the memory of passion - in tired postcoital moments, to listen to one's idol is to go from the loss of innocence to the recapture of candor" (as cited in Quiroga, 2000, p. 145).

Invented nostalgia is a "way to cope with life", according to Aurelio (personal communication, 2000). As Sprengler who researched nostalgia in cinema, writes, "(n)ostalgia surfaces in response to uncertainty, anxiety and dissatisfaction with the present" (2009, p. 31). Gays are known to be admirers of nostalgic music styles,

\footnotetext{
${ }^{17}$ Source: http://www.elpais.com/articulo/cataluna/Muntaner/acoge/ultimo/bolero/obra/critica/sociedad/cubana/elpepiautcat/1999 0120elPersComPersComat_28/Tes/

${ }_{18}$ The concept of "invented nostalgia" is not only an individual practice, but also known in its social/cultural context when deliberately used by culture institutions and planners (Chaney, 1997; Boym, 2002; Judd \& Kantor, 2006).
} 
nostalgic films, and collectors of nostalgic artefacts, but "nostalgia for a place one has never seen" as per the famous quote from Greta Garbo in the film "Queen Chrtistine" (1933). So is the case in Cuba. As was mentioned earlier in the book Strawberry and Chocolate, the film which represents more than anything else Cuban homosexuality (not only to Cuban gays, but also to non-Cubans and to Cuban heterosexuals), we see Diego, the gay hero, enveloped in nostalgia and thrives on it. His house is full of antique artifacts and memorabilia, and the music he likes and introduces to the young communist student David via his record collection, likewise, reeks with nostalgia. ${ }^{19}$

Nostalgia was coined as a medical condition (Boym, 2002, pp. xiii-xiv), however it was "demedicalized" in the mid twentieth century, taking its place between culture and psychology, and used for political purposes by "making sense of people's ongoing fascination with the material, visual and aural culture of times past... in a way that supported its emerging political used" (Sprengler, 2009, p. 31). Whereas Sprengler investigate nostalgia in the cinema industry, Kramer looked at invented nostalgia in music: "We hear modes of identity playing out their conflicted history, nostalgia being invented in the service of cultural purity, formal closure seeking both to subsume musical tradition (the long echo, say, of Beethoven's Fifth and Ninth Symphonies) and to distance itself from social upheaval" (Kramer, 1995, p. 198).

Invented nostalgia is also used in much popular music, especially when "authenticity" and the search for the "ethnic" and the "authentic" is involved. "Authenticity hangs on nostalgia" claim Connell and Gibson (2003, p. 272), as "(m)odernity demands its converse, tradition and even invented tradition, which becomes embedded within modernity" (Connell \& Gibson, 2003). The use of invented nostalgia in the service of cultural purity and to combat social upheaval is typical in neo-folklorization projects of "young" countries, using music, as well as other cultural forms in order to "create" a unifying folklore. "Bolero politics" is a good example. Bolero, once associated with the decadence of the night clubs of pre-revolution Havana, has been appropriated by the cultural authorities as a "national" heritage with a dedicated festival "Boleros de oro" (Golden Boleros) organized by The Union of Writers and Artists of Cuba (UNEAC). The official "invented nostalgia" effort in reviving bolero resonates well with the individual use of invented nostalgia among Cuban gays as "a way to cope with life", in the creation of a much needed emotional space. ${ }^{20}$

\section{Hysteria}

"Hysteric" is another term widely used to describe the performances of many bolero artists. The connection of hysteria and homosexuality dates back to the late nineteenth century medical discourse when hysteria was associated with women and effeminate. In his book Unheroic Conduct: The Rise of Homosexuality and the invention of the Jewish Man, Boyarin writes that hysteria was gendered feminine, applicable to both women and effeminate men, and more specifically Jewish men (Boyarin, 1997, pp. 192-193), and Elaine Showalter writes in her essay "Hysteria, Feminism, and Gender": “... hysteria in men has always been regarded as a shameful, 'effeminate' disorder", and the male hysteric assumed to be "unmanly, womanish, or homosexual" (1993, p. 289). Still, it is important to note that, for the purpose of this investigation, I use the term "hysteria" in its colloquial meaning, and not as a medical condition, indicating an exaggerated, out-of-proportion emotion leading to an uncontrollable over-excited behavior.

\footnotetext{
19 See also photo III/6.

20 The concept of "invented nostalgia" when deliberately used by culture institutions and planners is widely discussed in Urban Studies literature (Chaney, 1997; Boym, 2002; Judd \& Kantor, 2006).
} 
Richard Middleton touches upon hysteria in torch-song performances, and draws on Lacan and Freud while discussing masculinity and male performance in popular music. This description can be easily adapted to bolero:

...lyrics return obsessively to themes of hopelessness and death. Obsessional Neurosis - the condition towards which classic torch songs point, was considered by Freud to be a "dialect" of hysteria.... The obsessive refuses the question of sexual difference: The obsessional is precisely neither one (sex) nor the other-one may also say that he is both at once. (2007, p. 117)

As for the behavioral side, on several occasions I was able to identify "hysterical behavior" both among the performers (La Lupe, for example, was known for her frenzied performance), and among the audience. In the summer of 2001, I was invited to a private bolero fiesta in old Havana; the audience was mostly gay, but there were also some non-gay neighbors present. The amateur bolero singer known as "Carlito" frequently burst into tears, shouts and screams, followed by silent weeping - all classic symptoms of hysteria (unrelated to any evident personal incident, merely to the lyrics and the emotional intensity of the music). Carlito's behavior was not exceptional, and I was told of many incidents when amateur or professional boleristas broke down during a performance. "Of course the singer is 'only performing', but so, too, is the hysteric", writes Middleton (2007, p. 114), and paraphrasing on Freud's "dream-work", he talks about "song-work": "In both cases, what is performed is conflictual - the staging of a lack, of ambivalence, of 'multiple identifications'; paradoxically, it is a 'desire for the unsatisfaction' that is presented to our gaze..." (Middleton, 2007, pp. 114-115).

As for the audience itself, although "clinical hysteria" is quite rare, I have witnessed many incidents of hysteria-related behavioral patterns, such as uncontrolled tear-shedding, weeping, and melancholic expressions among the audience.

Interestingly, psychoanalysis has strongly connected hysteria with femininity and with gender ambiguity and destabilization. In the wake of Freudian theories, Lacan claims that hysteria derives from the question "Am I a man or am I a woman" (1993, p. 171)? Furthermore, Freud states that "the root of hysteria lies in a sexual fantasy — but the fantasy stands for a situation in which something has 'gone wrong', and the 'normal' course of desire has been blocked and refused" (Middleton, 2007, p. 114).

\section{Borders and Liminality}

"Being on the border, not here, not there" is another reoccurring theme in bolero psychology. "Bolero performances deploy and reconstruct borders", writes Quiroga (2000, p. 155). He explains that "( $t$ )he gash of sentiment is always a question of borders, and it works by turning every point of breakdown into a moment of reconstitution" (Quiroga, 2000). Other borders to be found, emphasized and exaggerated in the discourse of bolero, are those of me/you and masculine/feminine, "in ways that do not necessarily correspond to the ways gender acts out in the public sphere" (Quiroga, 2000), women can be defiant or aggressive, and men can be feminine, forlorn, destitute, or apathetic (Quiroga, 2000, p. 156).

This preoccupation with borders gives bolero its "gay-friendly" quality:

Boleros allow gay men to deploy and suspend the borders implicit in the genre, and to remotivate them according to their own wishes and desires. By mimicking the constitution of the borders, by erecting them again and again, gay men reveal that the only possible essentialism lies precisely in the hybrid arbitrariness of the border. By placing themselves on the border, they refuse marginalization. (Quiroga, 2000, p. 162)

Being constantly "on the border" means acquiring a liminal status, which is not necessarily marginalized 
or inferior, but rather a mobile, threshold status, "not outside of the social structure or on its edges, it is in the cracks within the social structure itself" (La Shure, 2005). Bolero can easily fit Turner's definition of liminality: "ambiguous, neither here nor there, betwixt and between all fixed points of classification" (1974, p. 232). In a previous description, Turner (1969) made he likens liminality to "being in the womb, to invisibility, to darkness, to bisexuality..."(2002(1969), p. 359). Darkness, invisibility, death, and sexual ambiguity are topics which are not foreign to bolero's lexicon.

Bolero "celebrates" its liminality on many levels - lyrics about uncertainty of love, feelings, social status; a threshold musical character which oscillates between European and African, between salons and plush night-clubs and clandestine drag shows and kitchens, between glamour and misery. Liminality is often connected with secrecy, and so is gay bolero, with its furtive, ambiguous connotations. The liminality of bolero poetry and its social status resonates well with the liminality of gay existence in Special Period Havana, where many gays find themselves "ambiguous, neither here nor there, betwixt and between all fixed points of classification” (Turner, 1974, p. 232).

Another aspect of the liminality of both bolero and gay life in Havana is their migratory/Diasporic nature. It is perhaps not a coincidence that most Cuban bolero divas and "gay icons" ended their life in the Diaspora, and were admired "clandestinely" by Cuban gays while officially were stigmatized as "traitors".

\section{The Bolero Divas}

In the dictionary of Hispanic gay and lesbian culture, Alberto Mira describes the divas' role in the gay world: "The divas have to make us believe that they live in their own sphere and that the norms and conventions which apply to everyone, do not apply to them. ...Perhaps the key to the definition of Diva is the way she inhabits her own myth, the way her life becomes better through her creations". ${ }^{21}$

Manuel, a 42-years-old bolero fan I met in the first bolero fiesta I described, and many times since in bolero fiestas at his home in Centro Havana, tells me:

We (gays) don't have "pop stars" like the straights do; we have divas that we can identify with. Like us they are larger than life, full of emotion and passion, lonely, surrounded only by some superficial admirers, but no real love, and considered bizarre and a bit crazy. Like us, they shed real tears, and tear into your soul with their roars and fingernails (He is particularly referring to La Lupe, known for her "roars"). Like them, we need the stage to survive, and, away from it we are a wreck. Like them, we are ridiculed yet desired in a distant way. Men will fantasize about our asses, but will not want to live with us, and like the divas, we too die lonely and sad. (personal communication).

Bolero is arguably the musical embodiment of the diva, even when sung by men-dramatic, painful, tragic, full of desire, longing, fantasy. I argue that not only that it is performed by divas, but the genre itself is of a "diva-like" nature, making the listeners feel and pretend to be divas along with the performer. Like the many drag queens I saw performing bolero onstage, in their kitchens, Aurelio and Angelito can shift in one breath from caressing their breasts or grabbing their crotches, to shedding real tears and waving their arms in anguish; exaggerated manifestations of pleasure and pain, pretending to be larger-than-life divas.

Both the diva and the bolero are sources of fascination and identification for Cuban homosexuals, especially those over 40 , who have had to live deeper in the proverbial closet. The explanation given by

\footnotetext{
${ }^{21}$ (My translation) The original text: "Las divas deben hacernos pensar que viven en su propia esfera y que las normas y convenciones que se aplican a todos no sirven para ellas. Y deben convencernos de ella a través de su arte, en el que se combinan siempre la mujer y el mito ... Quizá la clave que define a la diva es el modo en que habita su propio mito, el modo en que su vida supura en sus creaciones" (Mira, 1999, p. 235, as cited in Knights, 2001, pp. 4, 5).
} 
Knights for the attraction of gays to divas can be employed to describe the attraction of gays to the bolero genre as a whole:

The fascination they exert for gay audiences is complex and may be accounted for by many factors including: identification with the marginal, with an aesthetic of emotional suffering and intense pain, with risqué eroticism and excess, with the semiotics of glamour (Knights, 2001, p. 5).

Olga Guillot (1922-2010) and La Lupe (1939-1992) are the two Cuban divas that were present in the cassette or CD collection of every gay bolero fan I met during my fieldwork. They are admired for their music, their life stories, and their dramatic "over-the-top" stage personae. Guillot with her trademark stage gestures described by Quiroga as: "coital reminiscence: trembling lips, fingers of both hands moving as if caressing pearly beads in front of her face, and then moving down to trace circles in front of her stomach, down to her sex" (Quiroga, 2000, p. 145); and La Lupe for being "the craziest loca ("la mas loca loca") that the world of music has ever known" as describes Aurelio.

\section{Olga Guillot: "La Vida es una Mentira" (Life Is a Lie)}

One of the prototypes of bolero divas in Cuba was Olga Guillot, known as "La reina del bolero" "The queen of bolero"). Born in 1922 in Santiago de Cuba, Olga's family moved to Havana, where she had already been singing professionally, even as a teenager. In 1945, she started singing bolero at a night club. Three years later, like many bolero artists of the era, she traveled to Mexico and established a successful international career. Guillot strongly opposed the Castro regime and in 1961 moved away from Cuba. Not surprisingly, since then her music has been banned in Cuba, adding even further appeal to this "forbidden fruit" for Cuban gays.

I always kept my cassette of Olga, even when I was hiding from the police in the UMAP days, and still have it. It's in my collection together, with the pictures and love-letters from my lovers. It is in my little secret "homosexual box", a little safe storing my true identity, even when I have to pretend to the outside world that I am something else. (Juanito, 55, personal communication)

Just like Juanito, many gay bolero-lovers adore Guillot. During the Special Period, Olga Guillot was "brought out of hiding" and became the "kitchen bolero" diva of many over-forty year-old gays all over Cuba. Her speciality was, according to Quiroga, "the bolero of despair and eros, the song that produces the erotic charge of steamy sex under a red light bulb, or the one sung by the woman after the man has left her panting, and she hides a knife under the pillow on a creaking bed where the sheets are wet" (2000, p. 145).

Quiroga describes the audience at Olga Guillot's concert in Madrid in 1998 as "a sentimental community, constructed around La Guillot as signifier" (2000, p. 148). One might say that in Cuba there exists a "virtual sentimental community" composed of a network of Olga Guillot fans listening to her CDs and cassettes in the privacy of their homes. Cuban gays who have never had the chance to see her perform live, have adopted her as a symbol of escapism, fantasy, drama and resistance to oppression. Many gay bolero fans told me that they identify closely with the texts of her songs, like "La mentira" ("The lie"), and "Miénteme" ("Lie to me"), as it reflects their way of life-Cuban society accepts homosexuals, on condition that they "live a lie": they lie to others, and accept that others lie to them.

\section{La Lupe: A Woman on the Verge of a Nervous Breakdown}

La Lupe is perhaps the most extreme and subversive Cuban diva, with a disturbed personality and tragic life story and an outrageous stage performance which made her an object of admiration and identification 
amongst many Cuban gays I spoke with. Together with stained-glass Tiffany lamps and Swan Lake, Susan Sontag includes exiled Cuban singer Guadalupe Victoria Yoli Raymond, known as "La Lupe" in her list of examples which form the canon of Camp (Sontag, 1964). La Lupe's performances were a mixture of Camp, drama, hysteria, uncontrolled passion, and self-ridicule. She is "the craziest loca ('la mas loca loca') that the world of music has ever known" says Aurelio (personal communication, 2000). Guardian reporter Sara Wajid describes her performance, as seen in the documentary film "La Lupe-The Queen of salsa" (directed Ela Troyano, 2007): "Dressed in a skin-tight gold lamé cat-suit, she clutches her breasts, squeals 'Ay! Aieeyyee!' in mock pain, grunts and removes her gold stilettos..." (Wajid, 2008). ${ }^{22}$

La Lupe emerged from the world of bolero and filin, but took it to theatrical extremes. In pre-Revolution Cuba, she was already a cult figure, much admired by homosexuals but largely barred from the mainstream music industry. She was "the most outrageous female performer in Cuba at that time, breaking with social norms of decorum and passivity for women in her explosively dynamic performances" (Knights, 2001, p. 6). Wajid describes further:

In her shows she wore heavy makeup and revealing clothes more conventionally associated with putas (prostitutes). She would laugh wildly, cry, swear at the audience, bite and scratch herself, hit Balboa (the pianist) with her shoes, lift her skirts, sit on people in the audience and moan and groan orgasmically. (2008)

La Lupe's wild and controversial style gained her a dedicated small audience of outcasts and homosexuals in Cuba, but did not go down well with Castro's regime in the first years of the Revolution. In 1962, she left for New York, where Tito Puente, the "king of salsa" invited her to sing with his orchestra. Her wild performances became notorious and Puente, who began to feel threatened by her notoriety, fired her in 1968, complaining of her lack of discipline, and decided to fill the gap she had left with two drag queens, who were hired to "do Lupe". Later he found a new Cuban singer, Celia Cruz who eventually became the new "queen of salsa". La Lupe understandably felt betrayed.

According to Cuban director Ela Troyano, La Lupe was "an amazing artist who has never been given her due because she was black, and because her lyrics and her stance were very working-class" (Wajid, 2008). Her flamboyant and risqué stage persona and dramatic boleros turned her into a gay icon in the Latino world. Just like her songs, La Lupe's life-story is a series of tragedies, which adds a further dimension to homosexuals' identification with her.

In 1971 in New York she recorded two of her most famous and heart-wrenching boleros, "La tirana" ("The Tyrant") and "Puro teatro" ("Pure Theatre"). The latter became a "gay bolero anthem" among Latino gays in the United States, and later (via cassettes imported by visitors from Miami) amongst gays in Cuba. Without any airplay on radio, banned because of her betrayal by defecting to the United States, "Puro teatro", which was smuggled into Cuba by visitors from the United States, became an underground hit among Cuban gays, who readily identified with the lyrics at many levels, as described above. In an interview she gave the same year to Look magazine, La Lupe said: “I think people like me because I do what they like to, but can't get free enough to do" (Wajid, 2008).

In the late 1970s, her career declined. In her last years, La Lupe became a devout Christian, vowing never

22 "The Scandalous Queen of Salsa" by Sara Wajid, The Guardian, Wednesday, 1 October, 2008. Retrieved from http://browse.guardian.co.uk/search?search=La+Lupe $+\% \mathrm{E} 2 \% 80 \% 93+$ The + Queen + of + salsa\&search_target $=\% 2 \mathrm{Fsearc} \mathrm{h \& fr}=\mathrm{cb}-$ guardian 
to perform again, and died in poverty and obscurity in her early fifties. The story of her death in misery reached the gay community in Havana, adding yet one more element of drama and tragedy to her appeal and diva-dom.

\section{Conclusion}

Due to its discourse allowing queer and Camp interpretations, its tragic, rebellious and "deviant" heroes, and its melodramatic lyrics and performance style, bolero has a long history of appealing to Cuban homosexuals. In the needy and restrictive environment during the Special Period, and the dire lack of physical spaces for gay socializing and self-expression, this special appeal turned this particular musical form into an important emotional and psychological space for self-affirmation and consolation, mostly experienced at home.

Primarily an emotional space, bolero is experienced in private, where the music triggers a state of emotional transformation described in this essay as "bolero mode". As for bolero as a social space, in Special Period Havana gays could not afford to enjoy bolero in its natural habitat - the nightclub - partially owing to lack of money to cover the admission fees and to the restrictive and discriminating door-policy, described above. Thus the creation of a "sentimental community" around bolero, as described by Quiroga in relation to gays in other Latino societies (2000, p. 148), is restricted to private fiestas and drag shows, in which bolero divas are imitated by drag queens, and where gender ambivalence - one of bolero's hallmarks - is joyously celebrated. In drag shows, bolero is often employed as a comic element, but also as an outlet for feelings and desire, and as a means of expressing sexuality. Another way (the most common one) to enjoy bolero as an emotional space, is to listen to it privately (or with friends) at home, on pirated cassettes or CDs, and on the radio.

This essay has demonstrated bolero's inherently queer and ambiguous character, which causes the strong identification of gays with the genre. Popular themes in Bolero lyrics, such as danger, suffering, betrayal and lying, illusion and disillusion, and being "prohibited" resonate with the emotional and psychological (and sometimes even physical) world of many older-generation Cuban gays. Other common themes were extracted from the psychological layers of both bolero and Cuban gays: ambiguity, melancholia, nostalgia, hysteria, and liminality. As for the music - the "tension" between the "African" and "European" elements express a dual identity, ambiguity and a social/cultural conflict, oscillating between a strong Cuban identity and a "global"/Pan-Latin one, and resonate with the unstable social/cultural status of Cuban gays. Finally, the style of performance celebrates drama, passion, erotic tension, and above all Camp, a gay sensibility.

The relationship between bolero and the Cuban gay community is reciprocal. Gays maintain the bolero tradition, and bolero provides an important emotional space for gays in Special Period Cuba. This is a space for self-expression and an outlet for feelings of deception, betrayal, frustration, and sadness. It is a space for identifying with, and for experiencing a sense of belonging to a community. In this case, it functions as a sentimental community, an environment in which to express gay feelings freely, defying society's restrictions by allowing queer interpretations, and a chance to escape into an alternative world of drama, passion, and glamour, in complete contrast with the shabby reality of real life.

Yet another function of bolero, as Angelito (45) puts it, is its therapeutic value: "I practice 'bolero therapy' for my nerves. Whenever I feel this kind of lump choking me in my throat, I put on my bolero CDs, and the tears just flow. The neighbors hear my singing and crying" (personal communication).

To sum up, this essay shows how the three main functions of musical spaces in the Cuban gay ambiente - providing a sense of identity, an interface for interaction, and escapism, are fulfilled by bolero. At 
times the level of identification triggered by bolero even encompasses the genre as a whole. When I asked Aurelio, a forty-four-year-old bolero fan who spends most evenings listening to old bolero recordings in his kitchen, what bolero means for him, he replied: "Bolero? ¡Yo soy el bolero! (I am the bolero!) Passion, love, lies, heartbreak, drama... Bolero is the story of my life — beautiful, sad, dramatic, romantic, total ! I am bolero!”

\section{Referneces}

Acosta, L. (1996(1988)). “El bolero y el kitsch”. In Radamés Giró (Ed.), Panorama de la musica cubana (pp. 269-284). Havana: Editorial Letras Cubanas.

Aparicio, F. R. (1998). Listening to Salsa: gender, Latin popular music, and Puerto Rican cultures. Middletown: Wesleyan University Press.

Aparicio, F. R., \& Candida, F. J. (2003). Musical migration vol 1: Transnationalism and cultural hybridity in Latino America. New York: Palgrave Macmillan.

Aulicino, J. (2007). Me parece: el código secreto de algunas letras. Clarín.com Retrieved August 8, 2011, from http://edant.clarin.com/suplementos/cultura/2007/03/03/u-01373136.htm

Boyarin, D. (1997). Unheroic conduct: The rise of heterosexuality and the invention of the Jewish man. Berkeley, Los Angeles and Oxford: University of California Press.

Boym, S. (2002). The future of nostalgia. New York: Basic Books.

Butler, J. (1999(1990)). Gender trouble: Feminism and the subversion of identity. New York and London: Routledge.

Campos, R. A. (1991). The poetics of the bolero in the novels of Manuel Puig. World Literature Today, 65, 637-643.

Chaney, D. (1997). Authenticity and suburbia. In S. Westwood \& J. Williams (Eds.), Imagining cities: Scripts, signs, memory (pp. 140-151). New York: Routledge.

Connell, J., \& Chris, G. (2003). Sound tracks: Popular music, identity, and place. London and New York: Routledge.

Judd, D., \& Paul, K. (2006). American urban politics. New Yoek: Pearson Longman.

Knights, V. (2001). Performances of pain and pleasure (divas sing the bolero). Paper presented in the Institute of Popular Music Seminar Series, University of Liverpool, November 15, 2001. Retrieved March 12, 2008, from http://www.ncl.ac.uk/sacs/POP/papers/divas.pdf

Knights, V. (2006). Tears and screams: performances of pleasure and pain in the bolero. In S. Whiteley \& J. Rycenga (Eds.), Queering the popular pitch (pp. 83-99). New York and London: Routledge.

Kramer, L. (1995). Classical music and postmodern knowledge. Berkeley, Los Angeles and London: University of California Press.

La Shure, C. (2005). What is liminality?. In Liminality: The space in between (October 18, 2005, first version). Retrieved March 12, 2014, from http://www.liminality.org/about/whatisliminality/

Lacan, J. (1993). "Seminar III” in The psychoses 1955-1956 (1955-1956) (pp. 168-180). New York: W. W. Norton.

LaFont, S. (2003). Constructing sexualities: Reading in sexuality, gender, and culture. Upper Saddle River, New Jersey: Prentice Hall.

Middleton, R. (2007). “Mum's the word: Men's singing and maternal law”. In J. I. Freya (Ed.), Oh Boy!: Masculinities and popular music (pp. 103-124). London and New York: Routledge.

Mira, A. (1999). Para entendernos: Diccionario de la cultura homosexual, gay y lésbica. Barcelona: Ediciones de la Tempestad.

Morad, M. (2015). Fiesta de diez pesos: Music and gay identity in Special Period Cuba. Farnham \& Burlington: Ashgate.

Mungen, A. (2006). "Anders als die Anderen", or Queering the Song: Construction and Representation of Homosexuality in German Cabaret Song Recordings Before 1933. In S. Whiteley, \& J. Rycenga (Eds.), Queering the popular pitch (pp. 67-82). New York and London: Routledge.

Quiroga, J. (2000). Tropics of desire: Interventions from queer Latino America. New York and London: New York University Press.

Orovio, H. (2004(1981)). Cuban music from A to Z. London: Tumi Music.

Samules, D. W., Louise, M., Ochoa, A. M., \& Thomas, P. (2010). Soundscapes: Toward a sounded anthropology. Annual Review of Anthropology, 39, 329-345.

Showalter, E. (1993). Hysteria, feminism, and gender. In L. G. Sander et al. (Eds.), Hysteria beyond Freud. Berkeley, Los Angeles and Oxford: University of California Press. 
Sontag, S. (1964). “Notes on Camp” in Partisan Review. Boston University. Retrieved from http://interglacial.com/ sburke/pub/ prose/Susan_Sontag_-_Notes_on_Camp.html

Sprengler, C. (2011(2009)). Screening nostalgia: Populux props and technicolor aesthetics in contemporary American film. New York: Berghahn.

Sublette, N. (2004). Cuba and its music: From the first drum to the Mambo. Chicago: Chicago Review Press.

Turner, V. (2008(1969)). The ritual process: Structure and anti-structure. Piscataway, New Jersey: Transaction Publishers.

Turner, V. (1974). Dramas, fields, and metaphors: Symbolic action in human society. Ithaca: Cornell University Press.

Wajid, S. (2008). The scandalous queen of Salsa. The Guardian, October 1, 2008. Retrieved from http://www.guardian.co.uk/lifeandstyle/2008/oct/01/women.worldmusic

Zavala, I. M. (1990). El discurso amoroso del bolero. Casa de las Américas, 30, 123-129. 